\title{
THE STSTEM
}

OF

\section{Preserving Green Food In Silos.}

.111111111

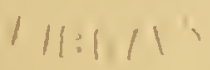

BI

PROHESSOR C. A. GOESSMANN.

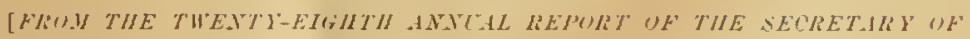
TIE STATE BUARI OF MRTCLLTLRE.]

BOSTON :

Liand, Aketw, \& Ca., f3rinters to the Commanwealt. 117 Franklin Streft. 


\section{THE SYSTEM}

\section{Preserving Green Food in Silos.}

BY

PROFESSOR C. A: GOESSUANN.

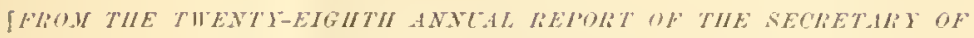
TIIE ST.ITE BO.1RD OF . WIRTCLTITE.]

$$
\vdots \vdots
$$

BOSTON:

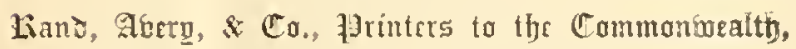
117 FRAXKLIN STRERT. 


$$
u^{-2.5}
$$






\section{TIE STSTEM OF PRESERVING GREEN FOOD IN SILOS.}

BY PIROFESSOR CIIARLES A. GOESSMAXX.

Mr. Chiminar, axt Members of the State Bodrd of Agrecletere, - Complying with an invitation of the Committee for the Arrangenents of this country meeting of the Board, I tike the liberty of asking your lind attention and inclulgence for the presentation of a few remarlis on the system of preserving green food in silos for the support of farm live-stock. The uncommon interest so generally manifesterl, of lite, in the discussion concerning the merits of the silo system for storing up green food, is but a deserved appreciation of the important agrieultural problem which that mode of liceping fockler, in the opinion of some of its adrocates, is destined to solve. As the question how to feed our farm lirc-stock in a rational and an cconomical manner can only be considered as second in inportance, in a general farm management, to the question liow to raise our farm-crops in the most economical way, it seems 
but judicious to investigate carefully any system of operation, new to our farm practice, which proposes to improve our present chanecs of securing economically an increased supply of green food, and thereby enable us to support more live-stock. The reduced area of linds serving as natural pastures, their quite frequently exhansted condition, the large demands for fodder in the dairy business, the increasing prospects of remmerative production of meat for the general market, the gradual change of an cxtensive system of general firming to an intensive one, - each, in it:s own way, tends to direct our attention to the consideration of the forlder question. Increased production of the foddercrops is the most characteristic feature in our modern intensive system of general farm management. In the prevailing intensive system of farming in the most successful districts of Europe, from one-third to one-half of the entire area of cultivated lands is devoted to the raising of fordercrops. The statement that plenty of foclder produces plenty of manule, and that plenty of home-made manure produces a plenty of remunerative crops, is there puite generally accepted as a safe rule. $\Lambda$ s the more prominent discussion of the silo system in our agricultural periodicals is, comparatively speaking, of a quite recent diate, and the actual tests in our farm practice are still of an cxecptional occurrence, it is not strange that quite opposite riews regarding its real merits in our situation find their advocates. This stage of opinion is apparently, in a linge measure, due to two circumstances: first, to a frequent misiplurehension regarding the composition and the feeding value of the silo product - the ensilage - as compared with the original green crop; and, second, to the adoption of a different basis for the estimation of economical points involved. Without intending to detract any thing from the well-deserved recognition of the merits of the valuable experiments of John M. Bailey, Esq., of Billerica, Mass., and others elsewlere within the country, or to anticipate the final results of their practical investigations, I propose to discuss in a few subsequent langes the silo system with reference to its listory in Europe, and from the stand-point of a careful scientific inquiry.

The preservation of green food in silos is at present mainly recommended for juicy plants, or parts of plants, 
and for certain vegetalule-refuse matter from sereral branches of industry. Prominent among these varions substances are the stalks and leaves of the Indian-eorn in blossom, the leaves of the sugar-loet roots, and the stems and leares of potatoes. Grass and clover in wet summer seasons, the refuse pulp of the leet-root from the beet-sugar manufaeture, and the potato refuse from the starch unanuficture, also diseased and frost-bitten potatoes, and roots of varions deseriptions, have been kept in silos, and thereby improved for feeding pmposes; and, finally, coarse grass-like plints, as rushes (Juncacex) and earices, or sedges (Cyperaceu), which in their green state are, as a rule, but little eaten by cattle. lave been prepared, in some instances, in silos, into a quite palatable and digestible cattle-food. The treatment of these and similar articles for their conversion into ensilage, or sour fodder, is usually earried ont in either dry ditehes or cemented cisterns especially eonstructed for that purpose. The green food, or the factory-refuse mass. after being reduced to a proper size for advantageous close packing, is put in layers, in the space prepared for it, and thoroughly trampled down, so as to leave 10 air-spaces in the mass. IJorses are frequently turned to account to seemre the desired compactness. In piling the material into the pits prepared for it, pains are taken to raise it, in the centre. to a conical-slaperl elevated top) somewhat alove the level of the surrounding ground, whilst on the sides it is kept somewhat lower: This eourse is pursued to prevent subse. quent depression in the centre of the silo. As soon as the packinrg-down is aceomplished, at least two feet in trickness of earth is filled mpon the mass, manally without using any layer of straw or boards to keep the vegetable matter and the soil separated from each other. The suceess of the entire operation depends on the dryness of the pit, the careful packingr-rlown of the miss in the silo, especially along its sicles, and the keeping-ont of the air, in partieular daring the earlier perior of fermentation. The contents of a carefully prepared silo soon mdergo a peenliar fermentation; in some instances, of an acid elaracter; in some of an indifferent or slightly alkaline character, which continues from one to two weeks, when they are ready for use: they keep in that eondition for from six to eight and more months. 
The original green food loses, during the period of fermentation, more or less of its weight, amounting, in some instances, to from forty to fifty per cent. This loss consists of more or less organic matter, and largely of water of vegetation. Very juicy articles shrink, for this reason, most: they are also apt to lose soluble constituents by leakage, in case the silos are constructed in a loose sindy or gravelly soil, instead of a compact soil or in cemented masomry. Some of the starchy or siccharine constituents are invariably transformed into lactic acid, - the acid contained in sour mills, - and other products chinacteristic of a sliny fermentation under the exclusion of air: in some instanees consiclerable quantities of alcoholic products and fitty acids are noticed. The nitrogen percentage of the ensilage is, for obvious reasons, usually higher thin that of the green food which served for its pruduction: although a small percentage of the nitrogenous constitueuts of the green crops is destroyed, and changed into compounds of ammonia or of volatile alkaline compounds of a similar character. The color and the ollor of the silo product dejends on the success of the treatment, and resembles more or less that of the material used: in case of green fool it is usually either daxk green or yellowish green. A failure of the silo process is readily noticed by a strong, unpleasant putrid odor, and the dark brown or black color of the regetable matter, which is also corered by fungi growtl.

As agriculturalists cliffer not only in the details of carying on the silo system in case of different materials, but also with reference to the same kind, I propose to describe subsequently some of the experiments of competent parties, to give a more comprehensive ideal concerning the silo system as carried out abroud. Having on a previous oceasion (Rejort, 1879-80, On the Feeding Valne of Corn) described the rules which guide us in our decision regarding the compirative feecling value of our varions articles of fodter, I onnit furtlee details.

Clover Ensilage. - The ditohes were three to four feet widc, and from four to five leet decp, with sides slanting slightly towards the centre. Sixteen cubic feet of space were connted for every ton of green red clover in blossom. The closely packed green clover filled two-thirds of the depth of 
the ditch, lined with compact earth; the remaining space was filled with the earth obtained from its construction; subsequently the soil was raised to from six to eight inches above the level of the surrounding ground. 'The contents of the silo, after ten months' lieeping, were found to be of a dark-green color, of a slightly acid re-action, and of an agreeable oclor. 'They were engerly' caten by cattle.

The composition of the clover (Trifolium pratense) bcfore entering the silo, and after its removal, was as follows:-

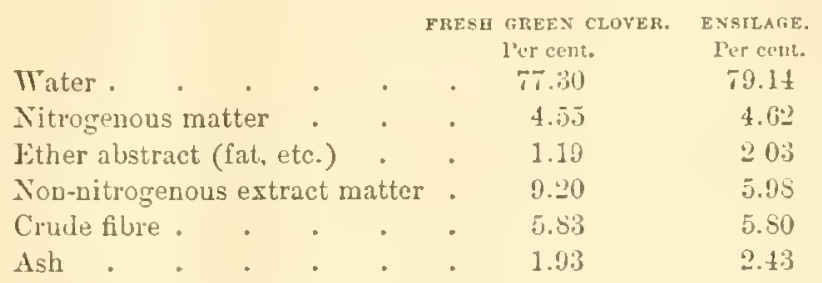

A sample of both substinces, calculated for a perfectly dry material, was found to consist as follows:-

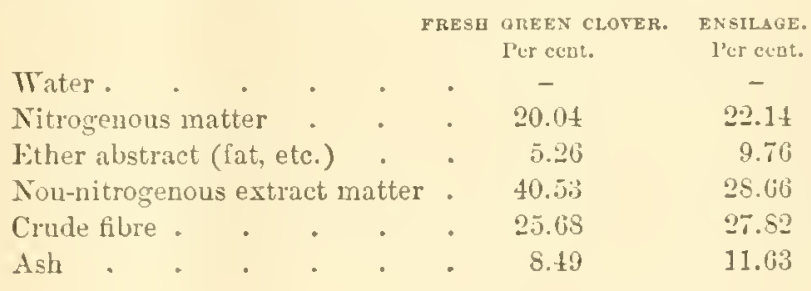

An cxamination of these analytical results shows that the amount of nitrogenous matter and the fatty acils have increased somewhat in the ensilige, as compared with the green clover; whilst the digestible non-nitrogenous matter of the clover has been recluced to from six to eight per cent in quantity. The total amount of organic matter destroyeci las not been stated: it is no doubt larger, and quite worthy of notice, judging from the results obtained in the sncceeding experiment, with a plant of similar character, - esparsette (Onolrychis sativa), cultirated saintfoin, - by II. Weisle.

Esparsette Ensilage. - The material whieh served in the experiment was cut on the 16 th of June. One portion of the green esparsette was carefully driecl, and saved for an analysis; another portion was packed tightly into a box, and 
buried in the contents of a silo of the previously deseribed construction. The silo was opened about tro months afterwarcts for feeding purposes. The box also was opened on that date, and its contents earefully dried and analyzed.

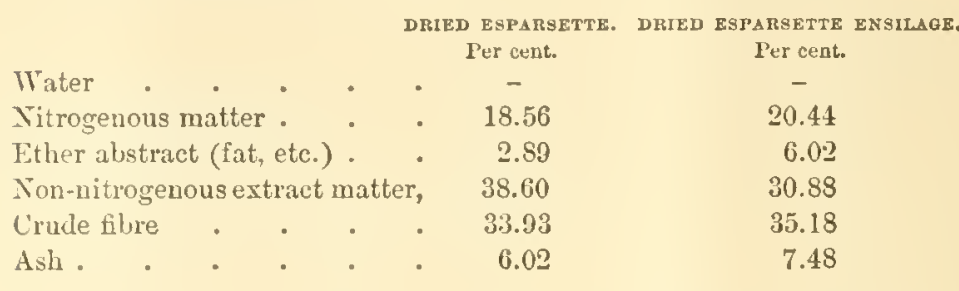

A careful weighing of the green food in the box, before and after the treatment in the silo, showed that twenty-four per cent of the organic dry matter of the fresh green plant hat been destroyed by fermentation.

Gruss, green lucem, and green lupine have been treated in silos with similar results. Quite interesting, in this connection, are the experiments with a mixture of green food and straw, to study the changes of the latter, as far as its subsequent feeding quality is concerned. Green rye and green vetch, with straw of wheat and of oats, were chosen for the investigation. As these two kinds of straw may be cut somewhat before the full ripening of the grains, without any injury to the latter, - a course which cannot be safely followed in the case of barley, etc., - they disintegrate, comparatively speaking, quite readily, and thus become in a higher degree digestible when treated in silos with green fond. liye and vetch were taken just before blooming. One part of either one of the two green plants, and twenty parts of wheat-straw, were eut in a suitable machine into pieces of about one to two inches in length: for every hundred pounds of straw there was adted from a pound to a pound and a half of salt. The green food and the straw were placed in alternate layers in the silo, and, after being trampled down, were covered in the usual manner with several feet in thiekness of earth. The silos, in this case, were filled in summer, and opened as late as Oetober, and their contents fed during the winter. The somewhat extended period of keeping them fermenting before feeding insured a proper softening and disintegrating of the straw, and therefore a higher 
degree of digestibility. The fodder produeed in this way had an odor and a taste similar to lay. Professor Toelcker, who speaks fivorably of this mode of operation, obtained the folluwing analytical results from the wheat-straw before its treatment, and after its removal from the silo.

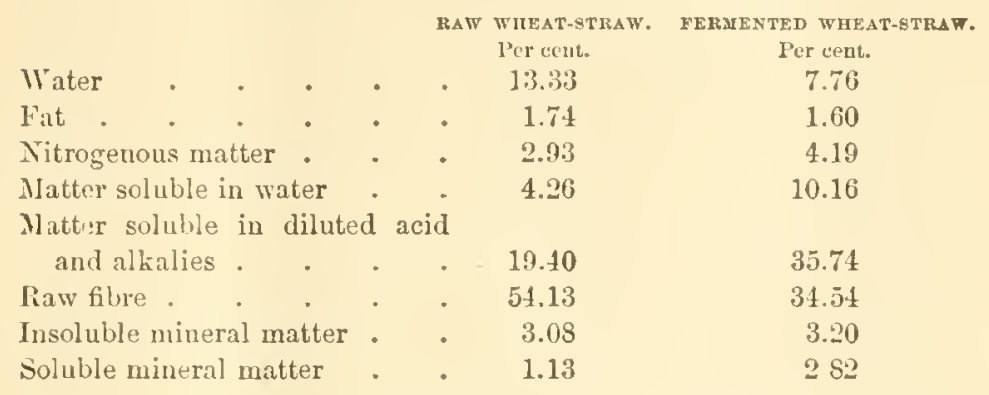

These results show a remarkable increase in the soluble and digestible matter of the straw, being raised from twentythree to twenty-four per eent, to that of from forty-five to forty-six per eent, not speaking of other favorable alterations in the original composition of the straw.

Leaves and Tops of Beet-Routs and Sugar-Beet-Root Pulp Ensilage. - The preservation of these refuse materials becomes a very important question wherever the agrieultural advantages arising from the introduction of the beet-sugar industry enter into consideration. They form the basis of an extensive system of stock-feeding for the meat-market and the dairy, which is invariably eomeeted with the leet-sugar industry in Europe. Assuming for the refuse-beet mass leaves, tops, and pulp - the same amount of moisture which is contained in the fresh beetroot (eighty-two to eighty-three per cent), its quantity amounts in weight to nearly one-third of the entire root-erop, or from five to six tons per atere (leaves, two tons; pressed pulp, three tons; and tops, one ton). As an illustration of the changes which the leaves and tops unclergo in silos, the following earefully condueted experiments may serve: A ditch from seven to eight feet deep, five feet long, and fire feet wille, was filled with alternate linyers of leaves and tops from the same lot of roots, until the solid trampled mass reached the lerel of the surrounding grounds. A layer of leaves, and subsequently it mass of earth several feet in thickness, served as a fina] 
eover. The silo was filled in October, and opened for use in the following March. To aseertain at the same time the exact loss in organic matter which the above-stated beet-root refuse wonld suffer in consequence of the fermentition in the silo, a definite quantity of the contents of the latter was cut out, and at once earefully packed tightly into a box, and buried in the centre of the silo. The latter was closed in October, and opened for use in Mareh. Leaves and tops had ehanged lut little in color. The ensilage in the silo had lost forty-nine per cent in weight, as compared with that of the fresh green material. The eontents of the box had lost by slow fermentation nearly one-fifth (eighteen jer cent) of the dry matter contained in the grcen food. The fresl material eontained 10.54 per cent of dry matter, and the ensilage only 8.44 per cent, These results demonstrate that juiey plants in orlinary ditches may lose as high as fifty jer eent of their solulle eonstituents, and that, even in exceptionally careful managed cases, a serious loss of their organic matter is mavoidable. The process, on the other land, liad increased the rate of the digestibility of the eelhular matter, and rendered the beet-refuse more palatable to cattle. ( $O$ Kellner.)

Analysis of Dry Matter, of Fresh Green Leaves, and of the Ensilage of Beet-Leaves.

\begin{tabular}{|c|c|c|c|}
\hline & & $\begin{array}{l}\text { FRESH GREEN LEATES. } \\
\text { Ter cent. }\end{array}$ & $\begin{array}{l}\text { ENGILAGE. } \\
\text { l'Cr cent. }\end{array}$ \\
\hline Nitrogenous matter & . & . $\quad 26.71$ & 21.23 \\
\hline Fat (ether alustract) & . & 2.75 & 8.79 \\
\hline Crude fibre & . & $1 \pm .99$ & 18.56 \\
\hline Non-nitrogenous ext & act matter & 37.13 & 39.42 \\
\hline $\operatorname{sh} . \quad . \quad$. & . $\quad$. & 18.42 & 12.00 \\
\hline
\end{tabular}

The pulp of beet-roots, olitained from beet-sngar factories, is treated in silos in a similar way. Frozen roots and potatoes are either erushed or sliced before they enter the silo, and frequently receive previously an addition of one per cent of salt.

A fer analytical statements in this connection may not be without interest, as they convey at least some approximate idea concerning the alteration which the sugar-beet root usually suffers before its factory-refuse mass serves as cattle-food. (Rittliausen; Voeleker.) 




Corn Ensilage. - The treatment of corn-foulder in silos has of late acquired considerable prominence in Austria and France. Both countries contain quite large areas of lanch, well fitted by elimatic conditions for an advantageous eultivation of corn. The successful and extensive application of the silo system in the sugar-beet inclustry of those countries has apparently greatly stimulated inquiries into its usefulness for general farm practice. In many instances in France, where the sugar-beet root is sold from a small farm to clistant sugar-factories, and high freiglit rates prevent the return of the refuse beet-root pulp to the root-grower, corn ensilage is used to make up the deficiency in fodder, caused by the sale of the root-erop. Our late lome experiments are apparently largely inspiren by the teachings of distinguished French agrieulturalists. As I lave reason to suppose that interesting descriptions of our lome experiments will be presented here to-day hy gentlemen intimately acquainted with that subject, I shall confine myself to the clescription of an investigation carried on at the agricultural experiment station at Tiemua, for the purpose of ascertaining the precise effect of the silo fermentation upon the composition of green-corn fodder, and the degree of loss which the organie dry matter suffers under that treatment.

The green-corn fodder was ent at an early stage of blooming, and, without any other preparation, carefully packed into silos of the usmal size and form. Sereral feet in thickness of earth served as a cover. An analysis of the green corn liefore filling the silo, and after its opening from two experiments, gave the following results:- 


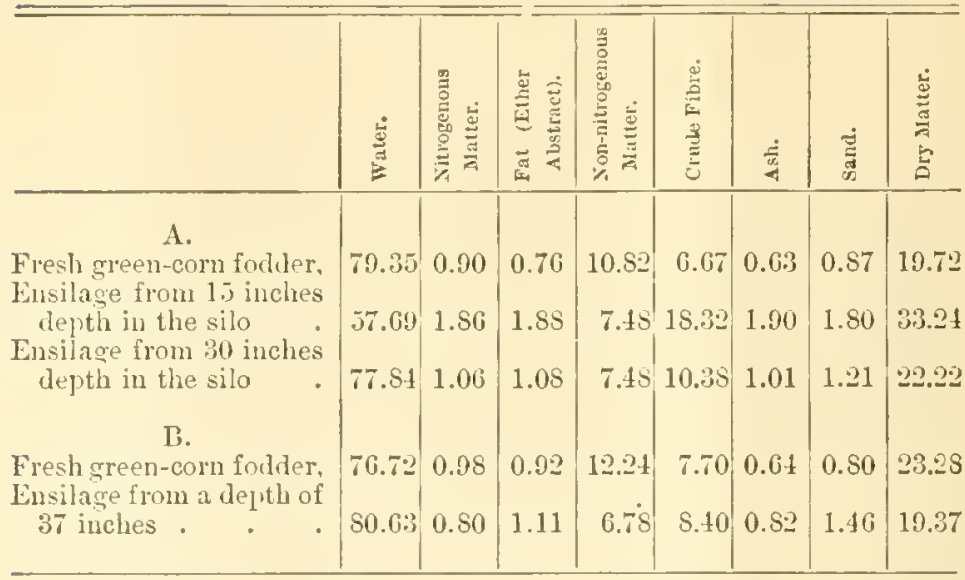

The following calculation of these results, calcnlated for the dry matter, gives a better chance to notice the changes of the latter in the green crop, as compared with the silo product: -

The Loss of the Dry Matter of the Green Crop in the Silos, stated in l'ercentages.

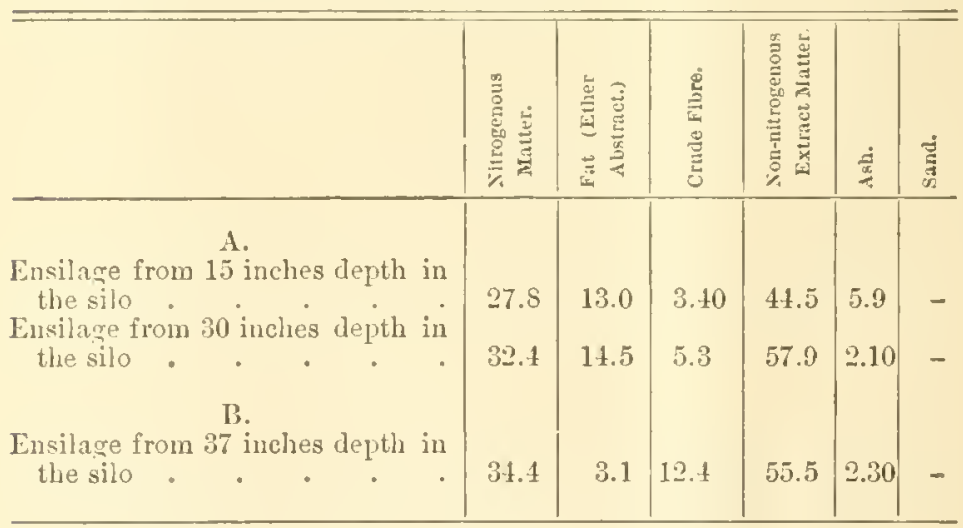

Both nitrogenous and non-nitrogenous extract substances suffered the largest loss. The slight alteration in ash constituents proves that but little, if any, organic matter was lost in any other way than by fermentation. The corn ensilage contained in both cases various alcoholic products, and considerable quantities of fatty volatile acids. A careful comparative examination (A) showel, that, at about 
fifteen inches depth in the silo, 27.9 per cent of the organic matter of the green-corn fodder had been lost, and, at a depth of thirty inches, 34.70 per cent; whilst in a second trial (B), at from thirty-seven to thirty-eight inches in depth, 34.8 per cent were lost. These results, in connection with those noticed in the previously deseribed experiments with beet-root refuse and esparsette, demonstrate plainly that the preservation of green folder in silos causes a considerable loss of valuable organie constituents, even when managed in an exceptionally careful manner. Those who are somewlat familiar with the transformation of starchy and saccharine substances into alcoholic produets, and subsequently into acids, know that in either case nearly one-half their weight passes off in a gaseous state, and are therefore expecting in the silo treatment the largest losses in those articles of green fockder which contain in considerable proportion one or the other, or both, of these widely diffused proximate organic constituents of plints.

The composition of ensilage varies in a not less degree, taking the entire contents of a silo into consideration, than that of the green crop which serves for its production. The same is true as far as the ensilage in different parts of the silo is concerned, as has been shown in the preceding pages.

Composition of Corn Ensilage from Different Silos.

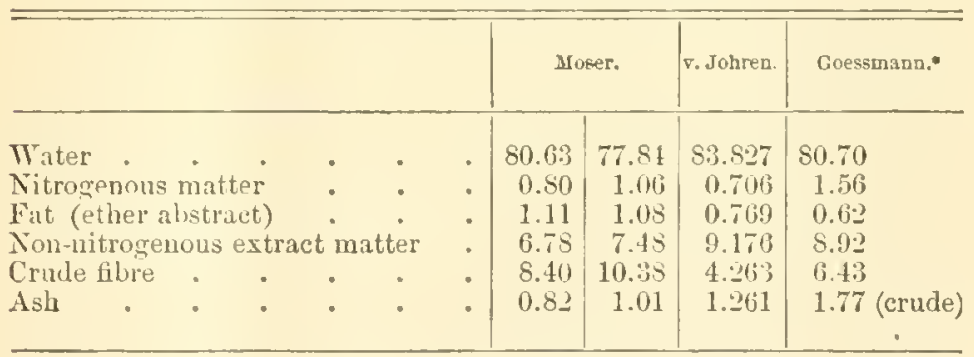

Some Extremes of Variations in the Composition of Green-Corn Fodder.

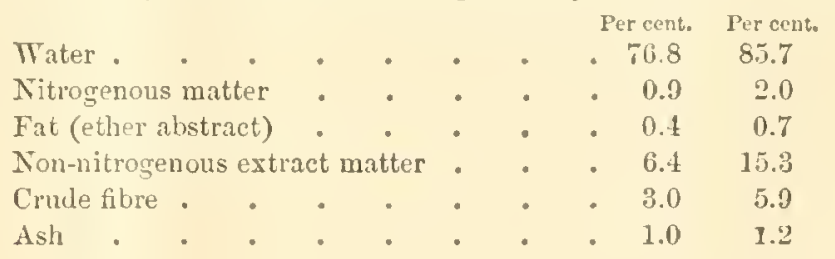

- From the silo of John Mr. Bailey, Esq., of Billerica, Mass, December, 1579. 
From the previous analytical demonstrations it will be quite obrious that the recommendation of the corn ensilage camnot well be based on its higher feeding value, pound for pouni, as compared with green-corn fodder. The inereased digestibility of the cellular matter in the corn ensilage, and the small, if any, increase of nitrogenous matter, is from a physiological as well as a commereial stand-point, to say the least, a donbtful compensation for the sugar and starch destroyed lyy the fermentation of the corn-fodder in the silo. An ceonomical and rational feeding of the corn ensilage, as well as the green-corn fockler, requires as a rule, except when fed for a mere sustenance, an adilition of a stronger article of food to meet the requirements of either growth, or work, or the production of milk and flesh. The silo system furnishes $n$ exception to the rule that our practical modes of preserving fodder are aceompanied with a loss in quantity and quality of valuable plant constituents, and that any attainalue higher feching value of our fodder-erops is almost invariably secured at the sacrifice of quantity. The question of waste is simply a matter of degree, when comparing existing modes of keeping fockler with that of the silo system. The correctness of the previous exposition once conceded, it remains for me to discuis bricfly some of the circumstances which tend to make the introuluction of the silo system a raluable arldition to our modes of keeping fodder, and thus of inereasing our resources for farm improvement.

'The management of the silo system for preserving fodder is independent of the weather, - an advantage of particular importance in the ease of juicy plants, so largely representerl among our fodder-plants. The long period required for their change into dry fodder, or laty, endiangers in a higher degree quantity, and in partieular quality, than in the case of conmon grass. Exposure of green crops to ratin, even for a short period, during the hay-making, alters the quality of the hay far more than usually suspected. A few analytical results may eonvey some more definite idea about the cxten of the change. 


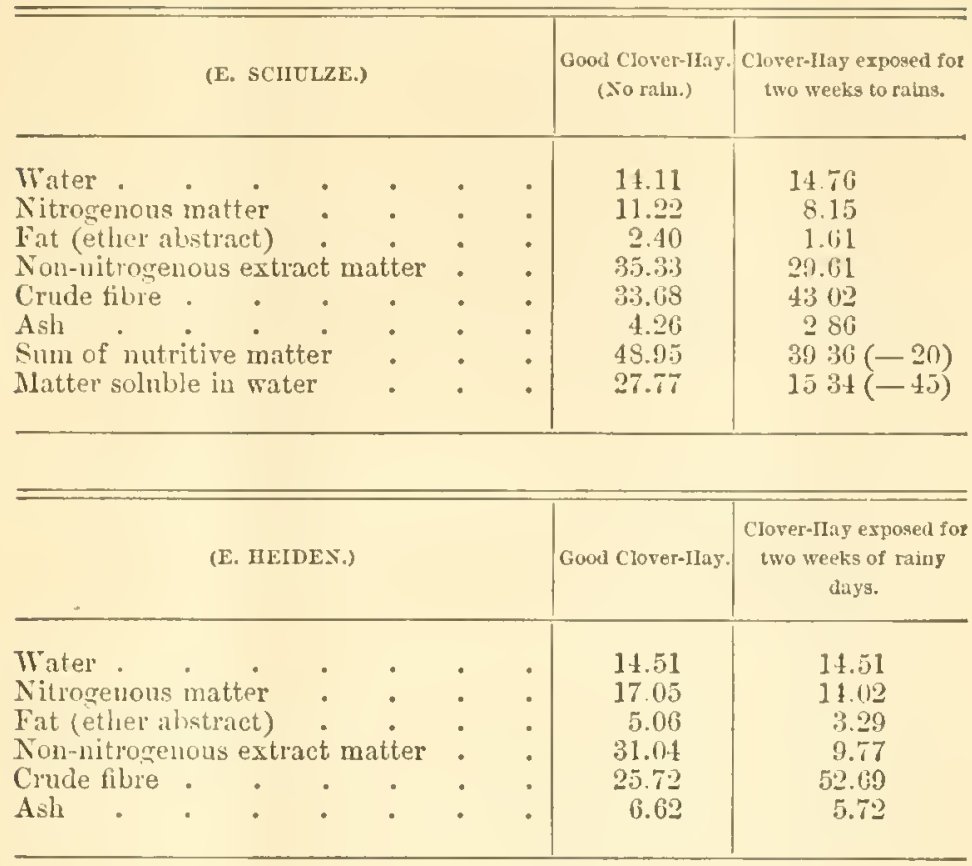

Good lucern-hay lost, in conserquence of an exposure to some rain-showers, within two days, 7.13 per cent of its dry matter (O. Kiellner); in another case, where the lucern-hay hat within six days repeatedly suffered from rains, a loss of 16.7 per cent of dry matter was noticed. The nitrngenous and non-nitrogenous soluble constituents of the plants are mainly affected by rain. The stage of growth, the more or less arlvanced state of dryness of hay, and the surromuding temperature, control here, to a large legree, the extent of the loss in soluble orgunic matter.

Fodder-plants like clover, with coarse juicy stems and tender leaves, usually suffer seriously in their leeding value, by frequent handling, from loss of leaves, which are the most mutritive parts of the plant. The loss clue to this source shows itsclf everywhere in the inferior digestilility of a common elover-hay, used in actual trials, as compared with earefully prepared clover-lay, where a large proportion of its leaves had been saved. The differences in the rate of digestibility of the various constituents of green clover and clover-hay, obtained from the same crop, arising flom the 
loss of leaves in the case of the clover-hay, has been noticed to amount, even in a careful farm management of lhaymaking in fair weatler, to from two to six per cent less of the sereral proximate constituents of the dry matter in the clover-hay. Observations on lucern confirm the previous statement. The following analytical results give some more definite idea regarding the amount less digested of each constituent in the case of clover-hay as compareil with the green elover. Cattle served for the experiment. (Kü̈hn.)

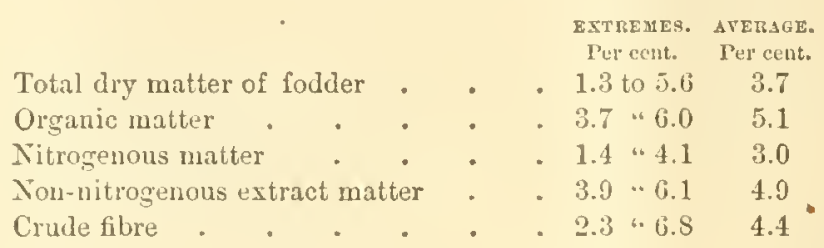

Careful investigation of a quite recent date (Kiilnn, Wolff, etc.) has proved that a mere drying of our common foddercrops, as grass, clover, and other leguminous plants, does not affect their rate of cligestibility. The green fodcler, and the dry fodder or hay (entire plant) from the same plant, in the same stage of growth, have shown a corresponding rate of assimilation of their dry substance. Whencyer, therefore, the production of dry fodkler can be carried on in a short period of time and in a satisfinetory manner, the largest amount of diry matter of the highest attainalule feeding value may be secured from the plant in that way: no other current mode of preserving its feeding rilue can equal it in regard to the quantity of the result. As, however, the quality of a dry fodder, as hay, clover, storer, etc., clepends on the influence of the weather, and the mole of handling and of keeping, - circumstances which arc to a large extent, in ordinary farm pratice, beyond personal control, - our various articles of diy fodkler are frequently fur from what they might be, or ought to be. The above few analytical statements regarding the loss, in case of the dry fodder, by waste, of the tencler parts of the plant, as well as regarding the influence of rain on lialf-dried fodder, give us at least a chance to approximate the loss, in nutritive constituents, from these two somees, which are liable to acquire unusual importance in case of those plants for which the silo system 
las been judiciously recommended. The ensilage contains, without any particular exertion, the entire fodder-crop, leaves and stems mimpaired. The quality and quantity of the ensilage, in case of a carefully constructed cistern and ordinary eare in management, suffers mainly from but one source, - fermentation. The waste of mutritious plant constituents in the silo appears, probably, to most of us large, even ruinous, because we have taken lut little pains to find numerical values for the depreeiation in the feeling value of our fodder-crops, which our current modes of preserving fodder are liable to permit or to faror.

Preferring actual results to mere approximations, and ascribing, therefore, to the silo system a higher rate of unavoidable waste of fueding value than to any other current mode of preserving fodder, it ought to be remembered that there are some redeeming fatures comnected with the product of the silo, - the ensilage, - for which it will be diffcult to find one definite numerical value when comparing it with the dry foclder of the same plant; namely, the silo fermentation increases the rate of digestibility of otherwise indigestible constituents (cellulur matier) of the green fodder, and thereby compensates somewhat for the waste of valuable soluble orgimic matter; and the ensilage of those crops for which the silo system is judicionsly recommended is amost invariably more acceptable to all linds of farm live-stock than the dry fodder.

When we ald to the previous enumeration of exceptional advantages arising from the introduction of the silo system the one that it will tend to inerease the prodnction of one of our nost important fodder-plants, the eorn, and that it will enable us eventually to take eare of important refuse materials from various branches of agricultural chemical inclustry, as sugar or stareh manufactme, we can but desire that its financial relation to our farm economy should receive the most careful practical investigation. The silo system is not a substitute for existing moles of preserving fodder, but will prove a most valuable assistance to increase our eliunces of securing larger quantities of good fodder. 

do is to rednee it to a certain lower proportion; and that is all that Mr. Goffart would claim. Probably his translators have not given us his full views. The process of fermentation is so well muderstood, that it is no longer a matter of controversy. Scientists agree on that entirely. The praetical results, at least, are fully agreed upon. We know what becomes of sugar in the presence of nitrogenous matter. We linow, that, whenever the cellular strueture of a plant is injured (as is the ease with the contents of silos in the majority of instances), transformation begins. The soluble nitrogenous matter comes in contact with the saccharine and starchy substances; and what is the effect? The sugar is ehanged, according to circumstances, either into lactic acid, or into alcohol and carbonic acid, and subsequently into acetic acid; and we find, therefore, in our best-constructed silos, with corn-fodder, acid to a large extent; namely, acetic acid and lactic acid. The former is the result of the oxidation of the alcohol. That is the natural consequence. Fermentation and oxidation are two distinet processes. The one causes the breaking-ul of certain substances into compounds of a simpler constitution; as, for instance, sugar breaks up into alcohol and carbonie acil. Nothing is lost from the make-np of the sugar. Acetic acid means the access of oxygen to the alcohol, and the formation of water. Alcohol and carbonic acid are only iutermediate processes. Therefore, if we are not careful, we may destroy the contents of the cells as starch and sugar to a ruinous extent. 111 other words, a silo treatment may destroy fifty per cent of the feeding value of your food. The above-tleseribed experiments tend to prove that we cannot prevent the destruction of from twenty to twenty-five per cent at least. Scientists do not agree as to the physiological value of the various componnds produced. In regard to stareh and sugar, we know by experience what they are worth in the animal ceonomy: what lactic acid is worth, we are yet in doubt, and what alcohol is worth is still a matter of dispute to-day. We have thus, in one case, compounds of recognized physiological value, whilst on the other side we have a series of products of decomposition without any proof of what they are relatirely worth in the auimal economy as compared with the substances from which they originated. 
There is, therefore, what I call unavoidable destruction in the operation of the silo system, as a partial fermentation is, in practice, still unavoidable.

Mr. WAre. I am very glad of the explanation; but I am sorry to have some of the starch taken out of the ensilage system. It strikes me that the box that has been spoken of, placed in the bottom of a silo, would not be compressed so solidly as a silo well loaded would be. If that is the case, I think it would account for a large portion of the destruction that took place in that box.

Now, in illustration, I would like to state one fact that has come under my own observation, that it seems to me is exactly in the hine of this silo preservation. I live on the seashore, and we on the seashore depend very largely upon the ocean for material for fertilizing purposes in the form of kelp. Kelp taken from the seashore, and exposed to the air, will, within thirty-six or forty-eight hours, even in winter, reach a state of high fermentation, and become so warm. that maggots will be produced even in the middle of winter Now, when we have a large amount of kelp come up on the shore, we go to work and team it up, loal after load, treading it down continually, until we have a pile perhaps eight or ten feet high, which becomes very solid; and two or three months after (although it is a substance that will ferment very rapidly, - as quickly as green corn foller), while the surface of that pile for the depth, perhaps, of ten inches, where it has not been troclden quite solid, will be badly decayed, the remainder of the kelp-leaves are perfect, the color is retained, and it seems to retain all the characteristies of the fresh plant.

Now it seems to me that here is an illustration of the operation of a silo. This kelp has been preserved, if you please, by this system of ensilage, in a perfect condition, with no appearance of fermentation having taken place. It seems to me that the great object in our silos is to follow out this simple illustration; that is, we must fill the silo so rapidly, and tread the green fodder so solitly, and load it finally so heavily, - as I understand, not less than twelve hundredweight to the square yard, - that the air will be expellesl; and it will be kept hermetically sealed from the air, so that fermentation cannot take place. 
Now I may be mistaken. I liave not gone iuto it, although I lave studied the matter carefully; but, if fermentation cannot be prevented in that way, I fear that our system of ensilage is not going to meet the expectations that I, at least, lad conceived of it.

Professor Goessuann. We apply the name "fermentation" to several changes which are taking place in vegetible matter. We have the vinous fermentation; and alcohol and carbonic acid are its products. We have the slimy fermentation; and lactic acid, a non-rolatile acid, is mainly prodnced. These latter changes are everywhere taking place where nitrogenous matter is mixed with non-nitrogenous matter under limited access of air. They are very serious, and camnot easily be prevented. It is a mere matter of degree. Take, for instance, a simple grape-berry. You can keep that locrry by drying it carefully, as is done on a large scale. But take that berry, and give it the slightest laceration with the finest needle you can conceive of, and that berry is gone. From that spot disintegration will take place, and it is only a question of :ime what shall become of it. It is an illustration of the process of destruction that is continually going on in the world. After life conses death. The moment that cellular system is broken, there is a retrograde movement, and the grape-berry goes back to its elements. So it is simply a matter of degree. I might say, of course, that the changes take place in different directions. In one case, it is lactic acid; in the other case, it is acetic acid. But what does it matter? A change from a valuable constituent of fodder into a constituent of very doubtful value is the result. We shall always find the largest losses in the ensilage in the corn; and, if we should take sugarcorn, it would be still more ruinous, as sugar is a most exsential constituent of that lind of corn; and for this reason, ordinarily, the decomposition of the sugar-corn would be far greater than of the common corn.

Mr. Cheever. Before the professor leaves the platform, I would like to ask him if our canned fruits do really keep perfectly in glass jars, sealed tight, put up boiling hot, or whether there is fermentation going on in those bottles.

Professor Goessmans. When you can your fruit, it being heated up to a certain high temperature, you bring 
it up to the point of the destruction of life. Fermentation is clue to living organism floating in the air. These living germs, coming in contact with vegetable matter, begin to develop, and will continue to develop just as long as their life lasts. If you heat up any article to be preserved to a point where you destroy the living organisms, and seal it up air-tiglit while hot, you will fail to find any alcoholic products in that can.

Mr. Cheever. Then the two cases of putting ensilage uito an air-tight box and canned fruit into bottles are not parallel?

Professor Goessmann. No.

MIr. Cheever. I suspect that box was filled as tightly as possible. If we know what influences the result, we shall be very careful to exclude that influence; and I suppose the parties considered that very carefully. They knew air was a destructive element, and, if they wanted to obtain a result worth any thing, they adopted a system which they thought would best bring about the result, and excluded air as much as possible. Taking that for granted, is not a tight box in the middle of a silo far better protected than any part of the silo?

Professor Goessmann. The only practical way to do it better is to turn in water at a certain stage, and let the water exelude the air. These experiments have, however, not been suffieiently tried to determine what the exact result wonld be. The water would probably dilute the material so much as to make it worthless.

Mr. Whitcuker. I should like to ask the professor, in connection with this matter of the exchusion of atmospheric air, a question which I think bears very seriously upon the point. In order to preserve any thing practically, as I understand it, we have either to get rid of the water, or get rid of the atmospheric air. If we retain the water, we must expel the atmospheric air: if we retain the atmospheric air, we must get rid of the water. Now, here is the point with regard to this ensilage business. We fill the silo, and, in filling it, we put in a certain quantity of decayed matter. Can that be avoided? I have always been taught that matter in a state of decay, however sinall it may be, will carry decay through the mass. It would not make any dif- 
ference if the silo was as big as this building, and filled full, if there was a piece of decaying matter as large as my fist in it, it would produce decay in the whole mass eventually. The entire exclusiou of atmospheric air will prevent that. But do re exclude atmospheric air from our silos? I do not believe it has ever been done. We fill the silo, and the natter we put in is loaded with atmospheric air. As it goes in, atmospheric air goes in with it. We put our plank on top of it, we weight it down, and we put earth on top in order to exclude the atmospheric air. But we liave all the atmospheric air in the silo that was in the material we put in, and, when we compress that, we simply condense the atmospleric air: that is in there, and, by condensing it, we render it more efficient to prevent fermentation. Is not that so?

Professor Goessmany. Oh, yes, sir! It is only a matter of degree. It is practically impossible to exclucte air absolutely. The simple question is, practically, Can we, with a moderate expenditure of time and labor, preserve our fodder in that exceptional way? If a simple mode of operation will not do it, the whole thing is not worth liaving; but, if a simple mode will accomplish it, it is. There is a partial loss whicl 1 is inevitable.

Dr. Sturtevant. In the changes which are taking place, there is a production of carbonic acid gas. which exclndes the air to a certain degree. In some cases, certainly, where an opening is eut down into the silo, and a lighted candle dropped in, the candle will be extinguished. This carbonic acil gas in some silos certainly expels the atmospheric air to a certain extent, occupies its place, and stops putrefactive cliange.

Professor Goessmann. There are two processes in operation in fermentation which we have to keep in mind: one is the action of air, and the other is the action of living germs. The exhaustion of the air amounts to very little, as you will understand when you know that one pound of sugar will dispose of all the oxygen in that silo, and leave nitrogen behind. Nitrogen takes its place. The presence of nitrogen exclucles air. As Dr. Sturtevant mentioned, if you put a light into the silo, it will go out as quickly as in earbonic acid. Therefore there are two canses which will 
dispose of the air. The destruction of the germ-life is a far more important question. That is disintegrating without air: that transforms all the constitnents, it changes the sugar, etc., into lactic acid without the aid of air. In our eanning system we get the germs out of the air: the heat destroys them. A little air we do not care about. A few grains of sugar will dispose of the oxygen of the air very effectually; but it cannot dispose of the germs that are there. They are living beings, multiplying by millions, and we know that those forces are most powerful. It is that continued multiplieation which destroys the plant.

Mr. Whitcaker. As I imderstand Dr. Sturtevant's point, it is, that, as the earbonic gas inereasel, the oxygen would be expelled; but, if the oxygen cannot get out, I do not know where it is to go. As I understand that the carbonic acid, wlien formed, is no greater in bulk than the oxygen that is contained in it was before it was converted into carbonic acil, this earbonic acid formed from oxygen will occupy just the same space, and no more, as the oxygen before it combined with the carbon to make earbonic acir. Consequently the atmospheric air wonlh he just as prevalent, notwithstanding it was mixed pretty well up with the carbonic acid. It would not be displaced, but would ocenpy just the same space that it ocenpied before it was combined.

Dr. Faxon (of Quiney). Among my labors at the National Sailors' IJome, of which I am superintendent, has been the reelaiming a lirge quantity of salt meadow, part of it covered with black gr:iss, which I cut yenrly, and used for bedding altogetlier. Last May I went to Billeriea, and saw the silo of Dr. Bailey, and I eoneluded that all there was to a silo was the exclusion of air: so I thought I would try the experiment with some of my llaek grass. I took a lot of old boards, and enclosed one of the end bays in the barm, ten feet by twelve, in the loosest manner, and I put into tlat all the blick grass I cut on two acres and a half of the marsh, and troul it down very thoroughly. I think I commenced on the fifteenth day of June, which was Tuestlay, and I finished on Saturdily. The grass was ent every day after the dew was off, and jut into the bay. On the baru-floor side I put up simply one upright three by three post, and put in the hoards. The heat was sufficient to be disagreeable to the 
liand, and people said the barn would burn up. When all was in, I put boards on erosswise, and loaded that grass, which was then abont eleven feet high, with stones, at the rate of at least a hundred pounds to the square foot, and redueed the pile as muel as 1 could. It sunk at least a third in bulk. Some four or five weeks afterwards - possibly it was not more than three weeks - I conmeneed on the front side, and took down the boards, ind ent off a strip about two feet wide, which had moulded for about three inches in. That fodder was a rich tobacco-eolor, and, instead of being acid to the taste or smell, it was positively sweet. It had a taste like honey. The flies came to it in swarms. I fed it to my cattle, and, although there was not a creature that would eat this black grass in its original state, they all ate it readily. My cows did not decrease in mill: they kept in just as good condition all through. I fed them almost exelusively on this fodder. I don't believe I gave two pounds of hay a day to the cows. Of course, there was some transformation in the product which rendered that fockler, whieh before was of little value, of considerable value. I an not going to discuss the question as to whether silo product is worth uore than the sane product would be if failly saved in a dried condition. I simply state the results of my experience, that any other man, if he chooses, may try the operation.

Questiox. IIow long did the grass remain in the field after it was cut?

Dr. Faxox. It was carried directly to the barn. Probably there was none of it remained an hour on the ground after it was cut. I fed it until miclsummer.

I tried another experiment about the same time. I had a lox that I had used to stean food in. I begin to ent my grass as soon as it is ligh enough, and feed it to my cows. I took that box, and put in probibly a ton of grass, and weighted it the same way; and at the end of three weeks it had developed quite an aeid smell and taste. You could not get any such sweet tiste ont of it as out of the black grass.

I will mention an experiment with corn-foclder. I lad a lot of fuckler that I cut in October. It was sowed the last week in July between my potatoes. I marketed the potatoes; and when the frost came, to save that fodder, I made a pit eiglity-four feet long, ten feet widle, and fifteen inches 
deep, and put the corn in this pit. On the edge of the pit, so as to make them flush with the inside edge, I put up a lot of old posts six feet apart; and I boarclerl up the sides five feet high, loosely, with hemlock boards. It took nearly a thousand feet. As the fodlder was cut when the dew was off, I brought it to the pit and laid it in, butts all one way, lapping the butts as one laps shingles, so as to make the small tops lie with the butts; and I carried that process out the whole eighty-four feet. Not having quite as much as I wanted, I carried down there five large tip-cart loads of fodder that was cut when the corn was, and from which the corn had been husked, and put that on top of the green fodder, which raised it above the boarding: I put on top a little thatch of eel-grass, and threw on fifteen or eighteen inches of dirt. When the mass scttled, the acid smell was scarcely perceptible. You could put your hand in five days after the first lot was put in, and the heat was not at all uncomfortable. You could feel it was warm.

Professor Goessmans. I can but confirm your olservation. The result depends entirely upon the composition of the plant. Grass and clover will produce an ensilage quite different from com. A plant which has little sngar will act quite differently from a plant that has a great deal of sugar. There is no need of having au acid : it may be even alkalinc. The main question is to prevent the clange from going beyoud a certain point, and injuring the feeding value of the material. Those plants which contain the largest amount of sugar will produce the largest amount of acid : therefore corn ensilage is usually somer than that from cluver or any other plant.

Dr. Faxon. The mass settled down so that it would weigh fifty pounds to the culbic foot. It was a little mouldy at one end for two or three inches; and I shovelled off the dirt, and cut that part out, and I found there was a great leal more acicl than there was in the bay of black grass. But the cattle ate that forlder just as well as they did the other, and the increase in milk was quite remalkable. I had been feeding shorts, forr quarts, cotton-seed meal and Indian-meal a quart each, daily. I diminished the grain within two clays just one-half, and the milk increased one-ciglitls; and I fed with that about five pounds of hay to each cow per day. 
The silo product is not mouldy anywhere. The fndder that was perfectly dry and put on top is eaten up just as clean as can be. By this simple method farmers can preserve their fodker in a moist conclition, so that the cattle will cat it all; and they can save labor, because it is much easier to put it in a silo in the field than to eut it u]). If you cut it up, it will heat tremendonsly in twenty-fom hours.

1 liave no doubt but that I shall raise a great deal of cormfodder, and put it up in that way, simply because it is handy ; and we can get more of it in that way than in any other.

I don't know but I should hesitale in regard to putting sugar-corn down in this way, after what has been said about it.

Professor Goessuraxy. It mould depend upon at what time it wats put in.

I)r. FAxor. I planted some green corn for market, and it gave me a littlo over twelve pounds of folkler to cach kernel. That was the Burr eorn. There were eleven thousand licrnels to the acre, and that is nearly sixty tons of green fodder. The land had been in grass seren years. I ploughed it up last year to kill the witch-grass ont of it. It had been top-dhessed nearly every year. and this last year it was mamured simply with a very little compost of hen-manure. I planted my corm the first day of May (rows four feet apart, one grain in a place a foot apiat); and along in July I cut some of it up for forlues, and got at the rate of sixty tous to the acre. I feed albout sixty pounds a day of the corn-fodder. 1)r. Builey says that is sufficient to feed a cow, without any liay : I do not think it is. I feed a little hay, and I think I get a better result.

Professor Goessmaxs. There is a point which needs explanation. Feeding corm-fockler, which differs in its composition from the requirements of the animal to support its life, can only he acomplistied ly the waste of one or the other constituents of the material. If we feed an article of foclder in which the nitrogenons matter stands to the non-nitngenous as one to nine, we give, in many cases, more non-nitrogenous matter than the animal requires. For instance, at milcl cow repuires, according to long-continued experiments, the proportion of one to five and a half. - almost onc-lalf nitrogenous matter more to give you the benefit of the other 
half of non-nitrogenous matter: in other words, you waste half. The same is true il you feed green grass alone, or lay alone, or clover-liay alone. The proportion of nitrogenous to non-nitrogenous matter in gool clover-hay is about one to three, or one to three and seven-tentlıs. Now, il a cow necds only the proportion of one to five, you waste a fair proportion of good fulder in that cluver-liay. The experiment has been successfully tried to see if we can supplenent our hay and elorer loy stratw, or by materials that contain one to nine, or one to ten. Here comes in the guestion of cheapuess of fueding, which the farner lass to sturly. "There is an actual waste of feeding value in fecding the lust laty without any adclition, under almost any comblions. That fact has been established by practice. 'Tle same is true with regard to clover-hay and othes leguminous plants. We are just beginning to liscuss this important fllestion of rational feeding; and we can never come to a decision, unless we take into consideration, besides the clatracter of the fodder, the particular requirements af the animal. If we fecd for sustenance mesely and for the production of milk on the same scille, we waste, in one way or the other, our food; and it is necessiry for us to learn in what proportion we can cconomically supplement ly lighter and inferion. articles of fodder our strong anticles of fodeler, as, for instance, gool elover or mcalow lay. It is important in consider the requirements of the animal with reference $t$, what it is to do. A horse to do good work requires a larger. relative anomut of nitrogenous matter than a lorse that stands idle. An ox which is liept through the winter simply for work in the spring ean be kept at a fal cheaper late than as ox that is put to daily labor. With us the question renatins, low to malie a practical alpulication of this lact.

I listened with a good deal of interest to the disenssion on feeding yesterlay; but, for one, l must say that there is 310 basis lor comparison. Without having any information regarding the quality of the fuchler which has been fed, how can we draw any reasonable deduction as to its fecding value? The question of quality is of the first importance. The discussion of ensilage, I think, has come up at the proper time. It may serve ats the means of stiring up the fudder question, which needs further ventilation (there can be no doubt about it) as much as the fertilizer question. 
Mr. Bowdirch. I would like to ask what the effect would he upon the fodder if a rain should eome up, and it should be wet as it was leing put into the silo.

Professor Goessiraxs. It would have no effect whatever. That is one of the great advantages. It render's us independent of the senson in regard to those crops which suffer unst from exposure.

Dr. WakEkLLD. We have listened to a very able address from Professor Goessmann on the ensilage system. Ile hais given us the facts in regard to the preservation of fodder in silos which cost considerable money. We lave lat an experiment given by another loctor, which any of us can try. It is within the meaus of anylyody lere who raises corn to try the experiment, because all he has to do is to plough up lis land, and make his silo in the field. I am rery much interested in this last jrocess, hecause it comes down to my means, and, I think, to the means of all of us. I do not see why, from his description, the fodder is not preserved substantially as well as in the expensive silos. He say's his cattle eat it readily, and he says his milk keeps up. Those are the two things that we want. The professor has stated here what is lost and what is gained by the silo, and he sarys thit it is necessary to exelude the air ; and the question in, llow much shall be exeluded? We eammot go inte the process of extracting the air loy an air-pump; but, if we can exclude it sufficiently by piling up some rough hemlock-boards it an expense of sometling like fifteen or twenty dollars, we can afford to do it if we can obtain a feed, which, in the main, answers the purpose just the same as if we lakl an air-pump in operation, and pumped all the air out, which would be too expensive a business for us to engage in.

It seems to me that this experiment is of vast importance to us. We have heard what the professor said here about "xperiments in Germany and lirance, and the experiments which are made in silos whieh cost a great deal of money. If we can lave the same alvantages, in the main, withont so nucl cxpense, then there is a great amount gainerl. Now. this ensilnge that Dr. Fiuxon lias brought liere looks like tolacco; but if his cows don't call it tobacco, and will eat it, ancl give milk in proportion, it does not make any difference 
whether it lias turned green, or gray, or dark-colored. We want the fucts in the matter, so that we may know whether we ean get the benefits of this system without too much expense. Here is a cliance, I conceive, to try the experiment. He has tried it on a cheap scale, and we can all try it in a similar manner.

Dr. Faxon. I wish to say that there is one thing which might make this cheap process of preserving fodder of value. It is very easy for us to buy oil-cake, or any nitrogenous commercial article; but if we can raise forty, fifty, or sixty tons of corn-folder on an acre, and by that means leep four or five eows in the ban'n, ind put the manure on the ground, it will cuable us to nse a good many acres that are of no value now. That is the point we are after. I will not take issue with the professor on the loss; but the question is, IIow much shall we gain? If we have land that does not bring in net five clollars an acre, if we can molke it yield fifty dollars an acre, there is so much gained. That is the only practical point there is aloout it. It enables us to save fodder that we conkl not save in any other way.

Mr. Jomsson (of Framingham). I suppose the matter of dollars and cents is to cone into this silo question, and therefore I venture to spealk of the cost of preserving fieldcorn. To talie sixty tous of green corn and ent it up into pieces an inch long, and put it into silos, is very expensive. I think Dr. Faxon has ilemonstrated thoroughly that corne ean be kept in the inexpensive way he has described. Now I wish to state, that in 1866 or 1867 I packed a bay of hay that was not in the field over an hour from the time the seythe dropped it. The timotlyy was not in full blossom when it was ent. I packed it so that it was all latid even and straight through the mow, and kept it as nearly air-tight as possible. The barn hat no cellar. The hay was packed close to the ground, with plank underneatli. That hay was thornughly preserved. It hat a fine lnown shade, and was the sw_etest and best hay for milch cows that I ever ferl. I could not put in my hay where there is a celkur unlemeath in that way. That lay was, as I have saic, thoroughly preserved, except about a foot in depth, which could not be kept as tight as the rest of the liay in the mow. I am confident that tho gentleman's theory is correct, and his experi- 
ment is correct every way; and hay may just as well be kept dried in that form, as dried three or four days, and lose half of its value.

The Chammas. Why didn't you go on getting your hay in that way?

Mr. Jounson. I did, until I got a cellar under my barn.

Mr. Sumons. The last gentleman who spoke left the inference on my mind that he thought the drying of hay was injurious. I understood the professor that drying did not injure it.

Professor Goessmanx. No crop loses in its feeding value by careful drying. It is the only process by which the ordinary feeding value of grass may bo preserved entirely. The making of brown hay, as Mr. Jolmson has clescribed, is a practice which is carrichl on, to some extent, here and there, and when we cannot dry our grass it comes in as a great help; that is, the loss is not as great as in a silo. But it is more difficult, and I suppose will be found more difficult to manage successfully than the management of a simple silo.

Mr. Williams. Wlat effect does falling dew have?

Professor Goessmans. The falling of clew is not of any particular consequence.

Mr. Wrliams. Then there is no disadvantage if we do not cock our liay up at nigldt?

Professor Goessmans. I have uever seen any evidence of it.

Question. Is there not always a loss when hay is stored damp enough, so that sufficient lieat is generatel to change its color?

Professor Goessurans. Yes, sir : there is no doult about that. Heat indicates a chemical transformation, a change of valuable material, no doubt. The difference between brown hay and ensilage is a mere matter of degree, nothing else. If brown hay is well managed, the procluction of it undoubtedly saves more than the production of ensilinge will. But as I understand, and general observation tells me, it is more cliffeult to prepare brown hay of good feecling qualities than to prepare good ensilage.

Questiox. Is it possible, in getting in hay that is not thoroughly cured, to treal it solid enough in the mow to preserve it any better than if it is not trocklen down? Can you exclnde the air by that operation? 
Professor Goessmann. Yes, sir: quite sufficient to reduce it to the smallest quantity. You will find the outside portion of the hay injured rather more than the interior part, because that affords a freer passage for the air.

Dr. FAxox. A gentleman just asked about putting in hay green to make brown hay. It should be known tha: it is not necessary to dry hay a great deal. I will relate an operation of mine, simply to show you how a large mass of partially dried green fodker ean le put in. Some seven year ago I mowed about ten acres of II ungarian grass, mixed with wormwood: it was almost as thick as it could stand. I finished eutting it at night, and left it until the next morning. The next day that stuff was as green as it could be. There was certainly as much as twenty tons of it, two-thirds or more wormwood. I made a stack of it, thatched the top, and it steamed there until February. I did not cut that down until August, the second year after; and there was not a brown straw in it: it was just as dry and fresh as it could be, showing that there was not enough water left in the stack to produce any organie ehange, or else that it all worked off in steam. That was the best lot of hay I ever saw of that kind. There was not a foot of it at the top damaged.

Major Eseny (of Lowell). I certainly, for one, have felt more pleasure, and been more benefited, by this lecture, than by any paper or any lecture I have ever hearl or read since I have been in the farming business. It seems to me that either chemistry must go under, or this silo business. I think chemistry las done more for farming than any thing else of late years. I think it has taught us more in the right direction, and in the end will produce more. It will revolutionize most of our modes of furming.

I have disensser this same subject with Dr. Bailey at Billerica; and, to show you how people look over the surface, I will name one thing that came np. He took the ground that fermentation created and brought out the sugar, which is entirely different from the filet. I took the ground that fermentation brought out the alcohol. Now, we have had the yellow-fever in the West, and we have laal a commission of the Bourd of IJealth to look after it, and see if there cannot be a stop put to it. We lave had the small-pox in many 
places, and we have had the Bourd of IIealth after that. Now the American people have the disease of silo on the brain; and we have a man here who has, I think, shown you the merits of it. I hope that the State Board of Agriculture will print this address in some form, so that every man who bas silo on the brain can read for himself, and malse up his mind whether he will have a silo or not; whether he will go according to the facts as given us by chemistry, or whether he will take the thing that first strikes his mind, because his cows appear to do a little better, and perhaps, the first week, will yield a hittle more milk. I think the lecture to which we have listemed is worth more than any paper that was ever put ont by any agricultural soeiety; and 1 hope that it will be published in such shape, that every farmer who can reacl and understand will know the exact benefits or disadvantages from excluding the air from this green food. I am not a chemist, and I do not know whether the ground taken by Mr. Bailey is right or not; but, when I have a piece of timber that I want to use, I turn it over to see if there is not a lnot on the under side. I hope the people will look this matter over very carefully before they spend any money.

Capt. Moone. I would like to ask Professor Goessmamn whether, in his julgment, there has been any improvement over the old plan of "making hay when the sun shines."

Professor Goessmany. No: I stated that most distinctly. There is no improvement over that nethod if the weather is favorable; but, as I said, the system of ensilage will be an assistance in saving, in many instances, a large quantity of valuable food. In unfavoralble seasons it will undoubtedly prove very valuable to the farming community, under proper management. I think simple ditehes will do. It is not necessary to have expensive masonry in a silo. A pit, if lined with boards to prevent leakage, will do as well on a moderate scale. The only difficulty albout a silo made in the gronnd, and unlined, is, that a large amount of the soluble portion of the material will be apt to leak into the lonse soil. I stated that in one case fifty per cent of the value hitl been lost by simple leakage in the ground. What we want to preserve is the nutritive portion of the fodder: and, if any part of it passes into the ground in form of a solution, much is lost; for the solution contains the most valuable portion of 
the fodder. It is for this reason not the proper thing to construct a silo in loose soil. It would be far better to line it with some suitable material, and use it year after year for the same purpose.

Mr. Whittaker. I want, hefore this meeting dissolves, to submit a resolntion; and I would like to state the reason why I submit it. When it was first annomeed that the Board of Agricuiture was to hold its annual session in Southborough, there was a good deal of eriticism elicited in eonnection with it. It was thought lighly preposterous to make the attempt to hold this meeting of the Board in a small plaee like Southborough, where there was not a lotel, within four or five miles of the town; and how we were going to manage it, and how we were going to get an audience to listen to the addresses that might be delivered, was a question that nobody could solve. When I came here the other morning, I supposed the meeting eommenced at the usual time, ten o'clock; and I got here about eight, in order to be present at the opening of the meeting. It seemed to me a remarkably quict place. It was so quiet, I could not get away from the idea that 1 hat made a mistake, and come up on Sunday. But that is not the point. $\Lambda$ t a great many meetings of the State lioard previously, it has been supposenl that it was necessilly to go to some jopulous centre in order to get an audience. This delusion las been dispelled in Southborough. As I unclerstand, the population of this town is not much orer twenty-five lnundred. We lave had very stormy weather. Yesterday wass an exceelingly stormy day, and yet this laall was full. I do not know what we should have done, if it haxl been a pleasint day, so that people could get here. This hall certainly would not lave been large enough to hold the audicnce. There are ladies enongh in Southlorough interested in this matter to fill this hall if it had been a pleasant day. They have been interested enough, small as the place is, to feed us, and feed us well. I do not know that we were ever better fed, better entertained, or better cared for in every respect at any place, however large.

Now, Mr. P'resident, I sulumit this resolution:-

Resolved, That the guests of the State lBoarl of Agriculture desire to express their thanks to the board for holding this meeting in a strictly agricultural district. 
The resolution was adopted.

Question. I would like to ask the professor one question: What, in his judgment, would be the effect upon domestic animals of eating the product of a silo day after day, and week after week, through the winter? Whether it would induce any disease in the stock? That is a serious question to my mind.

Professor Goessmaxn. Feeding exclusively ensilage in large quantities is not to be recommended. It ought to be supplemented, without doubt, in many instances, with some other stronger article of food. Ensilage contains frequently a large quantity of acid, and I should recommend that it be supplemented by something else to couteract the effect of the acid. For instance, give forty pounds of ensilage, and supplement with some hay, and similar, even strouger articles of fodder from time to time. No one article of fodder cau be used economically for all kinds of animals in different conditions, with equal advantages.

The Chatrmax. Before dissolving this meeting, in behalf of the Board of Agriculture I desire to express again our great gratification at this large and most intelligent audience. The meetings have been larger and better and more successful, I think, than any of the country meetings I have ever atteuded; and, while we feel thankful for our kind reception here, we certainly ought to thank you, in behalf of ourselves and our speakers, for the close attention which you have paid to the papers; and I believe you will be rewarded for this in the present, and still more when you receive the Secretary's Report.

And now, in behalf of the Board, I bid you farewell, and hope for a happy return to your homes. 



$-$ 


\section{LIBRARY OF CONGRESS}

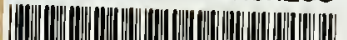

A

00027661889 